Síntese - Rev. de Filosofia

v. 40 N. 126 (2013): 43-72

\title{
OBSERVAÇÕES CRÍTICAS SOBRE UMA RESENHA DE GUIDO IMAGUIRE DA OBRA: \\ ESTRUTURA E SER. UM GUADRO REFERENCIAL TEÓRICO PARA UMA FILOSOFIA SISTEMÁTICA
}

(Critical remarks on Guido Imaguire's review of the book: Structure and Being: a Theoretical Framework for a Systematic Philosophy)

Lorenz B. Puntel*

Resumo: Este artigo responde pormenorizadamente às críticas feitas por G. Imaguire em sua resenha do livro indicado no título (= ES). Trata-se principalmente de nove temas respectivamente teses de caráter central para a concepção exposta no livro. $O$ presente artigo analisa cada um destes temas, em parte corrigindo erros de apresentação e de interpretação e em todos os casos respondendo às objeções de Imaguire. Trata-se dos seguintes temas/teses: (1) Para esclarecer o estatuto das sentenças filosóficas, ES propõe uma teoria dos três operadores que explicitam o caráter de sentenças: são estes o operador teórico, o operador prático e o operador estético. $\mathrm{O}$ artigo esclarece o sentido exato desta teoria. (2) ES apresenta uma nova definição de saber/conhecimento em oposição direta à já famosa definição "knowledge is true justified belief" articulada por E. Gettier. (3) ES defende uma concepção de orientação ontológica das estruturas formais fundamentais (lógicas e matemáticas); estas são esclarecidas. (4) Em ES é exposta e defendida uma nova concepção de ontologia em perfeita conformidade com a semântica de uma linguagem filosófica transparente; esta ontologia exclui o conceito de "substância" e critica o uso do conceito de "objeto". (5) ES expõe uma nova teoria semântico-ontológica da verdade que tem como consequência um relativismo * Universidade de Munique (Alemanha). Artigo submetido à avaliação no dia 29/08/
2012 e aprovado para publicação no dia 04/02/2013. 
moderado da verdade. (6) ES formula um argumento muito especial contra o fisicalismo; o artigo explica pormenorizadamente este argumento. (7) A concepção exposta em ES afirma que o cristianismo, em virtude do caráter racional e teórico da teologia que o explicita, constitui, em oposição a outras religiões, uma temática com prioridade de importância e atenção para o filósofo sistemático. Neste artigo esta tese é explicada e defendida contra interpretações erradas. (8) O oitavo tema é a grande questão posta pelo conceito de mundo no contexto das relações entre teorias filosóficas e teorias científicas. $O$ artigo esclarece uma série de mal-entendidos a respeito deste grande tema. (9) Finalmente, com relação a um argumento-chave que ES apresenta para fundamentar a tese que, por razões sistemáticas, se deve admitir uma dimensão absolutamente necessária do Ser, o artigo demonstra que a resenha comete um muito grave erro de interpretação, baseando neste erro uma crítica infundada ao argumento. $O$ artigo esclarece extensamente $o$ argumento, suas pressuposições e suas consequências.

Palavras Chaves: Estrutura e ser, críticas, respostas e esclarecimentos.

Abstract: This article is a detailed answer to G. Imaguire's criticisms of the book Structure and Being: A Theoretical Framework for a Systematic Philosophy (hence referred as ES). Imaguire focuses on nine topics that are central to the book. The present article analyses each one of these theses, sometimes correcting errors made and misrepresentations introduced by Imaguire, and in all cases, responding to Imaguire's objections. The theses are the following: (1) In order to clarify the status of theoretical sentences occurring in philosophical works, ES presents a theory about the three operators that make explicit the statuses of three mutually irreducible kinds of sentence: the theoretical operator, the practical operator, and the aesthetic operator. (2) ES offers a new definition of knowledge in significant opposition to the now-famous definition formulated by E. Gettier, "knowledge is true justified belief." (3) ES defends an ontologically oriented conception of the fundamental formal (logical and mathematical) structures. (4) In ES, a new ontology is propounded in strong conformity with the semantics of a transparent philosophical language. This ontology rejects the category of substance and criticizes the widely used concept of object. (5) ES presents a completely new semantico-ontological theory of truth. One of its consequences is a moderate relativism with respect to truth. (6) ES presents a unique argument against physicalism; this article elaborates on it. (7) ES considers the phenomenon of religion and states that, due to its rational and theoretical theology, Christian religion, in opposition to other religions, provides a uniquely promising resource for philosophical considerations. (8) ES extensively thematizes the concept of world in connection with the problem of the relationship between philosophy and science. (9) Finally, ES develops the main features of a theory of Being as such and as a whole. ES offers especially an important argument on behalf of the thesis that the universal dimension of 
Being must be conceived of as two-dimensional: as the dimension of absolutely necessary Being and the dimension of contingent beings. This article reconstructs the exact meaning of the argument and explains its presuppositions and consequences.

Keywords: Structure and Being, Criticism, Answers and Clarifications

$\mathrm{A}$

resenha de Guido Imaguire do livro do autor do presente artigo, indicado no título, ${ }^{1}$ é em grande parte uma boa resenha, pois expõe com fidelidade o objetivo e o caráter da obra e os grandes traços da concepção do seu autor. Este aspeto da resenha deve ser ressaltado, pois que o livro é de difícil leitura. Isso por três razões principais. Primeiro, pela enorme extensão do livro. Segundo pela amplitude da temática. Terceiro pelos conhecimentos que o livro pressupõe em diferentes áreas: história das grandes épocas da história da filosofia, a complexa problemática e temática da filosofia de hoje, sobretudo no plano da filosofia analítica, conhecimentos mais que elementares em lógica moderna e, em grau menor, em matemática.

Infelizmente, a resenha contém numerosas interpretações incorretas com respeito a pontos essenciais da concepção exposta no livro, sendo que sobre esta base incorreta são formuladas importantes críticas infundadas. O objetivo destas observações críticas é de examinar os principais pontos essenciais incorretamente interpretados e infundadamente criticados.

[1] O primeiro ponto a ser examinado é a teoria dos operadores. O livro ES distingue três operadores para esclarecer o estatuto de sentenças: os operadores teórico, prático e estético. Com isso cria-se clareza a respeito do que se exprime linguisticamente, sobretudo a respeito do estatuto das únicas sentenças que podem ocorrer nas ciências e na filosofia, a saber, as sentenças teóricas. O operador teórico, inspirado por uma formulação do Tractatus de Wittgenstein, tem a forma: "É o caso que (p. ex.: a terra gira em redor do sol)". Mas Imaguire afirma: "É questionável [...] se a introdução dos operadores resolve o problema como pretendia o autor. A sentença 'é o caso que

\footnotetext{
${ }^{1}$ PUNTEL, Lorenz B., Estrutura e Ser. Um quadro referencial teórico para uma filosofia sistemática, S. Leopoldo: Editora Unisinos, 2008. A sigla "ES" seguida da(s) página(s) documenta as citações deste livro no corpo do texto. A edição original alemã com o título: Struktur und Sein. Ein Theorierahmen für eine systematische Philosophie foi publicada pela Editora Mohr Siebeck, Tubinga, em 2006. A resenha de G. Imaguire apareceu na revista Filosofia Unisinos (9(3): 284-292, set./dez. 2008). Todas as citações desta resenha são documentadas no corpo do texto com a sigla "I" e a(s) página(s). Note-se que o autor da resenha cita somente a edição original alemã, tendo observado que não teve acesso à tradução em português. Algumas vezes no presente texto são citadas passagens da resenha, nas quais ocorre uma indicação a páginas da edição alemã; neste caso acrescentar-se-á entre colchetes a indicação da página ou das páginas correspondente(s) em ES.
} 
você sempre deve dizer a verdade' contém o operador teórico e é certamente sintaticamente bem formada, apesar da sua natureza claramente imperativa." (I 286)

Imaguire não analisa corretamente a sentença que lhe serve como exemplo. A sentença "é o caso que você sempre deve dizer a verdade" é certamente uma sentença teórica, pois que o principal operador, i. é o operador que determina o caráter da sentença integral, é o operador teórico "é o caso que...". A sentença "você sempre deve dizer a verdade", isoladamente entendida, sem a pressuposição do operador teórico explicitamente anteposto, é sem dúvida uma sentença prática, i. é uma sentença regida pelo operador prático "é obrigatório que...(p. ex.: se deve dizer a verdade)". Mas na sentença-exemplo de Imaguire este operador prático está no escopo do operador teórico que é o operador que determina todo o estatuto da sentença integral, na linguagem usada por Imaguire: que determina a "natureza" da sentença integral. Mas do fato que na sentença-exemplo é o operador teórico o que determina o estatuto da sentença integral segue-se que é falso dizer que a sentença (integral) possui uma "natureza claramente imperativa". $\mathrm{O}$ livro ES tematiza expressamente este caso, cuja estrutura formal é a seguinte: \{Operador teórico: é o caso que [operador prático: é obrigatório (sentença: dizer a verdade)]\}. A sentença "é o caso que você sempre deve dizer a verdade" é, assim, uma sentença teórica, não uma sentença prática. A sentença diz que é um fato que existe a norma (moral) de dizer a verdade. A sentença expressa a constatação deste fato, ela não articula uma norma; ela constata a existência da norma - nada mais, nada menos.

Por último: contra a tese do livro que seria sem sentido usar o operador prático tendo em seu escopo o operador teórico (exemplo de Imaguire: "dever ser assim que seja o caso que os seres humanos se respeitem mutuamente" (I 286)), Imaguire objeta que autores da tradição pragmática como Searle admitem legitimidade de tal caso. Mas este apelo à autoridade de alguns filósofos nada prova, pois que a afirmação em questão é um contra-senso e/ou uma confusão. Que significa dizer "deve ser assim que seja o caso que os seres humanos se respeitem mutuamente"? Pode-se interpretar tal sentença equívoca como querendo dizer: "Deve ser uma exigência (= operador prático) que todos os homens trabalhem no sentido de que seja (i. é: se torne) uma realidade (= segundo operador prático) que todos os homens se respeitam mutuamente." Imaguire não vê o que é evidente em sua própria formulação: "... que seja o caso que..." Ora: a frase "que seja o caso que" (= operador prático) é fundamentalmente distinta da frase "que é o caso que" (= operador teórico). Brevemente: Imaguire erroneamente interpreta a frase "que seja o caso" como operador teórico, confundindo "que seja o caso que" e "que é o caso que".

[2] Um segundo ponto criticado por Imaguire é a tese geral de ES sobre o que é saber/conhecimento. Aqui Imaguire, no início, apresenta uma interpretação pelo menos parcialmente correta da concepção exposta no livro, 
mas sua crítica, como se verá, se baseia em pressupostos errôneos. Primeiramente ele se refere, em consonância com ES, à definição de conhecimento formulada por Edmund Gettier em 1963, que se tornou clássica na filosofia analítica, mas que é muito controvertida. Trata-se da seguinte definição de conhecimento/saber: (DEF-CGettier) ("C" como abreviação de "Conhecimento"): $\mathrm{O}$ sujeito $\mathrm{S}$ sabe/conhece que (a proposição) $\mathrm{P}$ (é verdadeira) se e somente se as três seguintes condições são satisfeitas: (1) P (é verdadeiro); (2) S crê que P (é verdadeiro); (3) S está justificado em crer que P (é verdadeiro). Imaguire nota corretamente que segundo ES esta definição é circular, mas ele não mostra isso, como faz ES, a saber: A definição só tem sentido, se as três condições são satisfeitas. Mas está a condição (1) satisfeita? Para estar satisfeita, o sujeito deveria de qualquer forma saber/conhecer que P (é verdadeiro), de outro modo seria gratuito assumir esta condição. Mas então já se pressupõe que $S$ tem conhecimento de que P é verdadeiro: uma perfeita circularidade. ES apresenta ainda um outro argumento: Se já se pressupõe que $\mathrm{P}$ é verdadeiro, as cláusulas (2) e (3) perdem seu sentido, pois se tornam completamente supérfluas; com efeito, constando a verdade de $\mathrm{P}$, que mais se quer ou se pode exigir? Imaguire não toma posição com respeito a esta refutação, o que parece significar que ele a aceita.

Imaguire passa logo à concepção (definição) alternativa que ES apresenta, a saber: A cláusula (1) é completamente rejeitada, a cláusula (2) é mantida e a cláusula (3) é modificada, sendo posta no escopo do operador "crer/ crença" (de segunda ordem). A definição alternativa tem então a forma: (DEF-C)Altern: $O$ sujeito $S$ sabe/conhece que (a proposição) P (é verdadeira) se e somente se as duas seguintes condições são satisfeitas: (1') $S$ crê que P (é verdadeiro); (2') S crê que está justificado em crer que P (é verdadeiro). Em outras palavras: pela rejeição de (1) "verdade" só aparece na definição como função do operador "crer/crença" em (1'); pela modificação de (3) "justificação" não mais aparece como não estando no escopo de algum operador (S está justificado em crer que P (é verdadeiro)), mas sim como em $\left(2^{\prime}\right)$ como estando no escopo do operador (de segunda ordem) "crer ${ }_{2} /$ crença ${ }_{2}^{\prime \prime}$ (o sujeito crê $\hat{}_{2}$ que sua crença $a_{1}$ é justificada). É interessante notar que Imaguire não apresenta e não examina esta argumentação que introduz elementos completamente novos na vasta discussão que é conduzida há decênios sobre a definição "clássica" de Gettier.

O que Imaguire faz é apresentar um contra-exemplo: "A dificuldade desta proposta é clara: se 'é verdade' e 'é justificada' estão no escopo do sujeito, segue-se necessariamente um relativismo. De 'Paulo V crê que a Terra está no centro do Universo e Paulo V crê que está justificado em crer que a Terra está no centro do Universo' segue que 'Paulo V sabe que a Terra está no centro do Universo'." (I 286) Um exame cuidadoso do contra-exemplo mostra que Imaguire se comporta como um filósofo analítico no sentido tradicionalclássico dessa corrente: Ele usa, sem explicações e sem justificação, formulações tiradas da linguagem natural coloquial como se elas fossem claras e 
aptas para provar algo em filosofia. Isso aparece logo que se põe a pergunta: Que significa "saber" no contra-exemplo? Como entender esta expressão na frase aduzida? Mais adiante em seu texto ele afirma "que Puntel não definiu 'saber', pelo menos no sentido intuitivo e usual da palavra" (I 286). Mas qual é o "sentido intuitivo e usual da palavra 'saber'"? Como já se disse, esta palavra e a palavra "conhecimento" são usadas em muitos sentidos na linguagem comum e na história da filosofia, como ES mostra extensamente, principalmente no caso altamente significativo de Kant (ver ES seção 2.3.2.3, pp. 143 ss.). Imaguire parece assumir que a definição de Gettier articula este sentido. Mas então como responde ele à prova articulada acima de que esta definição é circular e que ela, assim, nada define?

Com respeito ao contra-exemplo, Imaguire aparentemente se apoia na afirmação implícita de que sua frase conclusiva "Paulo V sabe que a Terra está no centro do Universo" é uma frase inadmissível, pois seria contraditória. Mas este raciocínio só se segue se se assume que "saber" implica automaticamente "verdade simpliciter (i. é aqui: verdade que não está no escopo de um operador epistêmico [crença])", como na definição já clássica de Gettier rejeitada em ES. A argumentação de Imaguire constitui, assim, uma petitio principii completa: Ela usa como premissa aquilo que está em questão. Em base da definição de saber/conhecimento elaborada em ES a frase "Paulo V sabe que a Terra está no centro do Universo" tem uma interpretação absolutamente não-problemática: entendendo "saber" segundo a nova definição proposta em ES: "crer que (por exemplo) P (é verdadeiro) e crer que essa crença está justificada...", a frase do contra-exemplo, devidamente (re)interpretada, reza: "Paulo V [sabe, i. é] acredita que (é verdadeiro que) a Terra está no centro do Universo e que essa sua crença está justificada". Paulo V está errado - nada mais, nada menos.

No contexto da temática do saber/conhecimento Imaguire se refere ao que ES chama de concepção universal do sujeito ou, simplesmente, concepção do sujeito como elevado à dimensão universal, breve: sujeito como sujeito universal $\left(=\mathrm{S}_{\mathrm{U}}\right)$. Trata-se do sujeito destituído da sua particularidade, destituído de todas as suas volubilidades e flutuações subjetivas. É o sujeito que não mais se distingue da perspectiva absolutamente universal. Imaguire diz que apontar para tal sujeito universal "não resolve o problema". Mas Imaguire parece não entender o que seja a elevação do sujeito à perspectiva universal. Ele logo pergunta: "Quando se pode usar $\mathrm{S}_{\mathrm{U}}$ (= Sujeito Universal)?" (I 286).

A resposta é muito simples: Em cada sentença genuinamente teórica o sujeito universal ou (o que é o mesmo) a perspectiva universal é implicado/ a. Como ES amplamente mostra, a sentença teórica é a sentença que é estruturada pelo operador teórico "é o caso que..." e por uma sentença declarativa (como: "a terra gira em redor do sol") como argumento do operador. Fica logo manifesto que o operador teórico (e, com isso, a sentença 
completa composta de operador teórico e sentença declarativa) não contém nenhuma restrição de que ordem seja: sobretudo não contém nenhuma relação ou indicação a qualquer sujeito, qualquer situação, qualquer circunstância ou fator que pudesse de qualquer forma restringir a perspectiva universal. Se ainda se quisesse falar de "crer" aqui, então, como se mostra em ES, se trataria de uma "crença idealizada".

É interessante notar que o lugar onde se mostra mais claramente o que significa, em realidade, o sujeito universal ou a perspectiva universal é a ciência, sobretudo a física. Nenhuma teoria científica séria, quando exposta adequadamente, inclui a mínima indicação a um sujeito (seja ele mesmo o teórico que desenvolveu a teoria), a uma crença e a coisas semelhantes. A teoria como tal possui a estrutura: "É o caso que...(aqui então se incluiriam, p. ex., as sentenças da teoria da relatividade)". Este fator tão fundamentalmente importante foi praticamente ignorado tanto na história da filosofia como ainda é vastamente ignorado na filosofia de hoje. Imaguire não o leva em conta.

Aqui uma observação importante deve ser adicionada. O sujeito cognoscente não aparece explicitamente na sentença teórica; mas isso não significa que ele esteja ausente de modo completo. O que acontece é notável: já que o sujeito universal é o sujeito elevado à perspectiva universal, a menção explícita do $S_{U}$ é inteiramente redundante; o $S_{U}$ que é o sujeito destituído de todas as particularidades, é simplesmente identificado com a perspectiva universal. É neste sentido que o sujeito como sujeito universal "desaparece". Imaguire não captou nem o sentido genuíno nem o imenso alcance deste estado de coisas teórico.

Em vez de recorrer à estrutura das sentenças teóricas como resposta à pergunta "Quando se pode usar $S_{U}$ ?", como se acabou de fazer, Imaguire aponta para o plano pragmático numa perspectiva habermasiana: "Quando se pode usar $\mathrm{S}_{\mathrm{U}}$ ? Quando todos (ou a maioria) dos sujeitos racionais acreditam que P? De fato, Puntel mesmo reconhece, nas observações finais desta secção, que de $S_{U}$ acredita que $P$, não segue que P." (I 286) A isso deve-se dizer que a elevação do sujeito cognoscente ao plano universal nada tem a ver com algo assim como o assentimento universal de todos os sujeitos racionais, o que é algo de completamente fictício e, ainda que por uma espécie de milagre pudesse ser alcançado, nada provaria. ${ }^{2}$

A ideia correta subjacente a esta tese pragmática, mas erroneamente interpretada por filósofos pragmatistas de tipo habermasiano, é a ideia da elevação ao plano da racionalidade bem definida, que é a perspectiva universal, independente de crenças, convicções e quaisquer outras atitudes do

${ }^{2}$ Veja-se sobre isso a longa nota 16 sobre Habermas na p. 152 de ES. 
sujeito cognoscente. É a ideia cuja expressão linguística é a sentença teórica: "É o caso que ...". Neste plano racional teórico são aclarados conceitos e são apresentados argumentos. Neste plano absolutamente "objetivo" não se trata de levar em conta quaisquer atitudes de sujeitos, pois este plano pressupõe que sujeitos se elevaram ao plano universal, no qual só deve reinar a objetividade, a racionalidade. Crenças no sentido normal da palavra não têm vez neste plano. Se ainda se quisesse falar de "crença", seria só num sentido idealizado. Neste sentido valeria: De " $\mathrm{S}_{\mathrm{U}}$ acredita (idealizadamente) que P (é verdadeiro)" segue que "P (é verdadeiro)". Imaguire se equivoca quando afirma: "Puntel mesmo reconhece [...] que de $\mathrm{S}_{\mathrm{U}}$ acredita que P [é verdadeiro], não segue que P [é verdadeiro]" (I 286). ES estabelece exatamente o contrário (ver ES 158). Só no caso de se atribuir ao sujeito universal algo assim como uma crença "normal" (subjetiva, nãoidealizada), esta conclusão não seguiria. Mas tal atribuição contradiz diretamente o estatuto universal do sujeito elevado ao plano universal da racionalidade e da teoreticidade.

Por último cabe aqui fazer algumas importantes observações sobre uma afirmação que Imaguire faz no contexto do seu contra-exemplo acima exposto e examinado. Ele afirma que o autor de ES "mais tarde na obra, de fato sugere a defesa explícita de um relativismo epistêmico" (I 286). Sem dar precisões, Imaguire certamente quer referir-se à secção 3.3.4.3 de ES com o título "Uma forma moderada do relativismo da verdade". Mas Imaguire erroneamente fala de um "relativismo epistêmico". Em verdade, em ES tratase de um relativismo moderado (i. é: não-autocontraditório) da verdade, o que, segundo ES e usando uma terminologia exata, é um relativismo semântico-ontológico e não um relativismo "epistêmico" ou "epistemológico". Notese, porém, que na literatura filosófica, principalmente no Brasil, costuma-se neste caso falar de (uma espécie de) relativismo "epistemológico". A razão disso tem raízes profundas e significativas. Esta terminologia é o resultado de colocar o sujeito - e assim toda a dimensão epistêmica/epistemológica - no centro da filosofia, submetendo a ela também as dimensões semântica e ontológica. ES mostra que isso constitui uma ignorância da dimensão teórica. "Conhecimento" é uma atividade ou um estado de um sujeito, enquanto que frases teóricas não contêm nenhuma relação a sujeitos ou a quaisquer outros fatores externos à dimensão da teoreticidade. Mas não é possível elaborar este ponto neste artigo.

Acrescentam-se aqui mais alguns esclarecimentos sobre o relativismo moderado da verdade, como é defendido em ES. Este relativismo é o resultado de levar a sério dois fatores dificilmente contestáveis. Primeiro: deve-se reconhecer no plano da teoreticidade uma pluralidade de quadros referenciais teóricos. Segundo: o que é verdadeiro (respectivamente falso) num determinado quadro teórico será considerado - pressupondo o princípio da bivalência - como falso (respectivamente verdadeiro) a partir de outro quadro referencial teórico - e não num sentido absoluto, i. é sem referencialidade 
(a outro quadro respectivamente grau). Um exemplo elementar pode ilustrar este ponto. Considere-se a sentença: "O sol nasce e se põe todo dia". Tratase de uma sentença verdadeira, mas só no sentido de ser verdadeira no ou relativamente ao quadro teórico do mundo da vida comum. Fica claro que está correto designar a sentença como verdadeira (nesse sentido) no momento em que a pessoa que profere a sentença é confrontada com a negação da sentença: "Não é o caso que o sol nasce e se põe todo dia". Se a negação da sentença "o sol nasce e se põe todo dia" for proferida dentro do quadro teórico do mundo da vida comum, a negação é falsa. Em ou relativamente a um outro quadro teórico, a saber, o científico, a sentença naturalmente não é verdadeira e sua negação, por conseguinte, é verdadeira, mas precisamente a partir do quadro referencial teórico da ciência astronômica. Esta referencialidade da verdade a quadros referenciais teóricos tem validade também - e principalmente - dentro da grande esfera da cientificidade (à qual pertence - ou deveria pertencer - também a filosofia). Também aqui e principalmente aqui há diversidade de quadros referenciais teóricos. Este ponto é da maior importância para se entender toda a história da(s) ciência(s) e da filosofia.

O que isso mostra é que o "fenômeno" chamado verdade não é algo simples, uma questão de "sim-ou-não-e-ponto-final", senão que é um todo grande e complexo constando de muitas facetas e, sobretudo, de muitos graus. A escala de graus de verdade corresponde à escala de quadros referenciais teóricos. A pluralidade de quadros referenciais teóricos não deve ser entendida no sentido de uma pluralidade de diferentes possibilidades ou opções de igual estatuto teórico, situadas por assim dizer no mesmo plano, sem diferença de estatuto ou grau. Antes, um quadro referencial e, assim, um grau de verdade não é igual a outro, é inferior ou superior a outro(s). O critério para um estatuto superior (respectivamente inferior) é extensamente exposto em ES: o critério é dado pela coerência e inteligibilidade superior (respectivamente inferior).

Não há verdades (resp. falsidades) simplesmente absolutas no sentido de serem completamente independentes de qualquer quadro referencial teórico. Não ter visto e não ter seriamente levado em conta este estado de coisas constitui um dos grandes erros da maior parte das concepções tradicionais da verdade, sendo que as outras poucas concepções, que não cometeram ao menos não explicitamente - este erro, foram em regra articuladas de modo puramente intuitivo, impreciso e inadequado. Verdade como tal e, assim, verdade absoluta não é verdade que consta independentemente de todo e qualquer quadro referencial teórico (na literatura fala-se neste caso imprecisamente e inadequadamente de "pontos de vista", "paradigmas" e coisas semelhantes); a verdade absoluta é a verdade que consta em todos os quadros referenciais teóricos. Isso se mostrará mais adiante, na parte [5]. Destas considerações segue-se que o relativismo da verdade defendido em ES não pode e não deve ser considerado (e chamado) um relativismo "epistêmico" ou "epistemológico". 
[3] Com respeito às teses de ES sobre as estruturas formais fundamentais (lógicas e matemáticas) Imaguire afirma: "Puntel quer tornar plausível a ideia de que até mesmo a dimensão formal tem um estatuto ontológico. Parece-me, no entanto, questionável a sua conclusão de que operadores lógicos têm um estatuto ontológico só porque eles podem estruturar coisas reais (Puntel, 2006, p. 244 [ES p. 241])." Imaguire afirma que a tese de ES é questionável, mas não indica razões. Implicitamente ele se baseia na tese comumente aceita de que lógica e ontologia são duas dimensões completamente distintas. ES questiona esta tese, pois ela não é inteligível. Com efeito, que sentido teria assumir que itens ontológicos são conectados a itens completamente distintos da dimensão ontológica? Teria tal conexão algo a ver com os itens ontológicos? Mas o sentido do emprego de itens lógicos/ matemáticos consiste em precisamente esclarecer o que acontece no plano ontológico; seria absurdo admitir que este emprego teria o sentido de construir conexões somente "na nossa mente".

Imaguire também afirma: "Também parece bastante problemática a qualificação de sentenças que estabelecem a sintaxe da linguagem - e que não são enunciados com pretensão de verdade numa certa linguagem $\mathrm{L}$ - como 'declarativas' e passíveis de valor de verdade. Tais sentenças são normativas, e não declarativas." (I 287) Ao dizer isso, Imaguire incorre na confusão entre ciência/teoria e didática. Em geral, nos livros didáticos de lógica, costumase dizer que a lógica é uma disciplina "normativa", pois estabelece regras a serem aplicadas (as regras de uma argumentação correta). Em vistas ao ensino da lógica não há nada a objetar contra isso. Mas a lógica entendida como disciplina normativa não é a lógica como ciência ou como teoria, assim não corresponde ao que a lógica essencialmente é. Essencialmente a lógica é uma disciplina estrutural; o que se chama de "regra lógica" é só por assim dizer o lado pragmático da lógica como sistema estrutural.

Um exemplo esclarece este estado de coisas. Tome-se a assim chamada regra da introdução da conjunção de duas (ou mais) sentenças/proposições (verdadeiras). No plano da didática usa-se para isso uma linguagem pragmático-normativa, p. ex.: se alguém aceita p (como verdadeiro) e aceita q (como verdadeiro), então é-lhe permitido, mais fortemente: é-lhe obrigatório admitir também a conjunção de ambas. Expõe-se esta regra p. ex. da seguinte maneira:

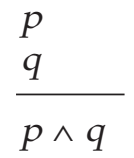


Mas esta regra só é válida porque é a "tradução" pragmático-didática de uma estrutura da lógica proposicional/sentencial, estrutura que pode ser articulada assim: $(p, q) \rightarrow p \wedge q$. Esta estrutura pode ser parafraseada da seguinte maneira: duas (ou mais) sentenças/proposições (verdadeiras) num sistema lógico sempre estão conectadas elementarmente pela estrutura conjuntiva. Não há aqui nada de normativo, há só a dimensão formal estrutural - é esta dimensão a que unicamente entra em questão para uma tematização filosófica da relação entre lógica e ontologia.

[4] Com respeito à ontologia "contextual" elaborada no capítulo 3 de ES Imaguire observa, entre outras coisas: "Puntel identifica, neste contexto, talvez rápido demais, substância com objeto. Objeto é, para ele, apenas uma outra expressão para a categoria de substância (Puntel, 2006, p. 254 [ES 2512]). Dada tal identificação, Puntel se considera legitimado a concluir que sua crítica ao princípio de composicionalidade semântica vale como uma refutação de qualquer ontologia de objetos. Penso que aqui seriam necessárias distinções mais finas." (I 288)

Parcialmente, Imaguire tem razão; apenas ele poderia ter descoberto na coerência da concepção exposta o que ele reclama: as "distinções mais finas" estão pelo menos implicitamente incluídas na exposição. Deve-se partir da constatação que o conceito de substância, que provém de Aristóteles, sofreu no decurso da história da filosofia muitas modificações, que, à primeira vista, dão a impressão que este conceito através da história da filosofia se transformou num conceito equívoco. Para aclarar esta complexa situação, ES propõe o critério lógico-semântico da predicação para caracterizar o conceito de substância, independentemente da questão se o conceito proposto em ES corresponde ou não a todas as acepções que foram dadas à palavra "substância" na história da filosofia. Predicação acontece sempre quando uma linguagem e uma lógica de predicados (em última análise: de primeira ordem) são pressupostas e usadas. Há então a seguinte figura lógico-semântica fundamental: uma propriedade ou relação $F$ é predicada de um a (= constante) ou $x$ (variável), que serve de base. Tem-se então: $F a$, respectivamente $F x$; a constante a respectivamente a variável $x$ (quando quantificada) possuem aquele valor ontológico, que constitui a base ou o sujeito da predicação.

Há diferentes "graus" de predicação e, assim, diferentes "níveis" com respeito a $a / x$ : Sempre que uma determinada base ou um determinado sujeito $a / x$ de nível $n$ pode por sua vez ser predicada/o de um base ou sujeito mais profunda/o $n+1$, a base/o sujeito não é a/o última/o. Quando a base/o sujeito não pode ser mais predicada/o de algo mais profundo, a base ou o sujeito é um indivíduo no sentido forte ou robusto: corresponde àquilo que Aristóteles chama de substância. (Quanto à interpretação de Aristóteles, haveria muito a dizer; mas isso, no presente contexto, não só não pode ser feito, já por não ser de importância maior, pois aqui se trata somente de 
explicitar o critério que ES elabora para aclarar o que, no livro, é chamado de ontologia da substância. En passant, seja observado que o autor de ES insinua claramente que o critério lógico-semântico da predicação é implicitamente pressuposto por praticamente todos os grandes filósofos, em cuja filosofia o termo "substância" desempenha um papel importante, independentemente das formulações das quais estes filósofos fizeram uso e independentemente da questão se estes filósofos, ao usar predicações de maneira habitual, davam-se conta ou não das enormes implicações ontológicas deste procedimento.)

Agora é possível esclarecer com facilidade a questão da relação entre "objeto" e "substância. Como é sabido, a filosofia analítica faz um uso quase excessivo do termo "objeto". Isso se deve ao fato que esta filosofia usa a linguagem e a lógica de predicados de primeira ordem como sua linguagem filosófica tout court. Resulta disso que, sempre que ocorre uma predicação, um "objeto" é especificado como a palavra usada para denominar o valor ontológico do a ou $x$ (quantificado) envolvido. Conforme este uso abrangente do termo "objeto", não se pode dizer que "objeto" no uso analítico e "substância" se correspondam inteiramente. Uma diferenciação ulterior se faz necessária. Também o uso de "objeto" ocorre em diferentes graus ou níveis. Quando o termo "objeto" é usado para designar o a ou o $x$ (quantificado) da predicação e quando este a ou $x$ (quantificado) constitui o grau ou o nível último da predicação, sendo que então a ou $x$ (quantificado) não podem mais ser predicados de uma base e, assim, de um "objeto" mais profunda/ o, então - e só então - há a coincidência entre "objeto" e "substância".

[5] ES defende um relativismo moderado da verdade, segundo o qual todas as verdades são relativas a (pelo menos) um quadro referencial teórico. Esta concepção não exclui verdades absolutas; mas as redefine como verdades em todos os quadros referenciais teóricos. Imaguire expõe com clareza esta concepção. Mas depois acrescenta: "Vale notar [...] que os exemplos mencionados por Puntel para verdadeiro em todos os quadros referenciais teóricos são duvidosos, a saber o princípio de não contradição (lembre-se da lógica paraconsistente) e o princípio de razão suficiente (que certamente não vale em todos os quadros referenciais teóricos)" (I 289). A questão levantada por Imaguire é justificada pelo fato de ES não elaborar este ponto importante. Mas não é difícil esclarecer a questão. Para isso deve-se distinguir entre o núcleo último das verdades absolutas e suas diversas formulações. O núcleo permanece idêntico (pelo menos num sentido geral intuitivo-prospectivo) nos diferentes quadros referenciais teóricos, mas as formulações mudam.

Imaguire diz que o princípio de razão suficiente "certamente não vale em todos os quadros referenciais teóricos". Mas tal afirmação é resultado do fato de ignorar por completo a distinção recém-feita entre núcleo do princípio e formulações do princípio. Que a formulação famosa de Leibniz "nihil est sine ratione" não tenha validez em todos os quadros referenciais teóricos, pode-se e deve-se conceder sem mais, principalmente pelo fato de não ser claro o que 
se deve entender exatamente por "ratio". Reduzido ao seu núcleo mais profundo, o princípio diz que nada é sem uma conexão, sem coerência; ou ainda em outras palavras (o que corresponde mais à concepção estrutural-sistemática de filosofia): que nada está fora de um contexto sistemático.

Um exemplo particularmente interessante e importante é o princípio de nãocontradição. Segundo Imaguire esse princípio interpretado como verdade absoluta é "duvidoso"; para fundamentar esta afirmação ele simplesmente acrescenta: "[...] lembre-se da lógica paraconsistente", mas ele não explica em que sentido e por que razão a lógica paraconsistente constituiria uma objeção à tese de ES que o princípio de não-contradição é uma verdade absoluta. Neste caso trata-se de um problema mais complicado, para cuja solução a distinção entre núcleo do princípio e diferentes formulações do princípio é de importância decisiva; mas ao mesmo tempo, é decisivo acrescentar algumas explicações essenciais. Duas considerações poderão aclarar a questão.

Primeiramente, é altamente instrutivo comparar duas famosas e muito bem conhecidas formulações deste grande princípio. A primeira se encontra na Metafísica de Aristóteles e reza: "É impossível que o mesmo (atributo) pertença e não pertença ao mesmo item simultaneamente e sob o mesmo aspecto." ${ }^{\prime 3}$ A segunda formulação é a formulação sentencial ou proposicional geralmente admitida hoje: $\neg(p \wedge \neg p)$ : é excluído que se possa admitir (a sentença/proposição) $p$ como válida/verdadeira e (ao mesmo tempo) a negação de $p$ como válida/verdadeira. A lógica tradicional clássica admitiu e admite o grande princípio chamado: ex contradictione quodlibet (=ECQ), de algo contraditório (i. é, de duas sentenças ou proposições contraditórias) segue qualquer coisa. Admitia-se e admite-se que uma concepção (uma teoria, um sistema lógico), que contém contradições, revela-se como sendo trivial, pois daí se segue que tudo vale; mas se tudo vale, nada vale. A lógica paraconsistente consiste fundamentalmente em não aceitar ECQ (pelo menos ilimitadamente). Daí não se segue necessariamente que lógicas paraconsistentes admitam que haja contradições verdadeiras, pois paraconsistência é (só) uma propriedade da relação de inferência. Mas a corrente que se chama "dialeteísmo (em inglês: dialetheism)" admite que há contradições verdadeiras; para não cair na trivialidade, o dialeteísmo deve aceitar uma lógica paraconsistente.

Não é possível entrar aqui em maiores detalhes, pois esta questão é imensamente complexa. Só duas observações serão feitas para esclarecer a questão se o princípio de não-contradição pode ou deve ser considerado uma verdade absoluta. Primeiro: o problema fundamental que a lógica consistente levanta é este: como entender exatamente e como "localizar" o que de maneira geral se chama "contradição"? Dever-se-ia distinguir entre dois conceitos de "contradição": contradição em sentido absolutamente estrito

${ }^{3}$ ARISTÓTELES, Metafísica, 1005 b 19-22. 
(forte) e conceito em sentido amplo (fraco). Em base desta distinção haveria que dizer: ECQ vale irrestritamente no caso da contradição estrita/forte, mas não necessariamente no caso da contradição ampla/fraca. Pode-se ver já em Aristóteles a tendência de tornar precisa a noção de contradição: de fato, ele acrescenta à sua formulação as duas restrições "simultaneamente" e "ao mesmo tempo". Na formulação sentencial/proposicional acima mencionada do princípio de não-contradição só é usado o conceito de negação. Mas negação é um conceito altamente complexo.

A fim de entender o que a lógica paraconsistente intenta fazer e defender, apontou-se acima para a necessidade de distinguir entre um conceito estrito (forte) e um conceito amplo (fraco) de contradição. Em que consiste concretamente esta distinção, não foi e não pode ser mostrado aqui; a razão disso é que é precisamente isso o que constitui o problema e a tarefa centrais da lógica paraconsistente. Esta lógica deve aceitar esta distinção, pois, como foi mostrado, ela, de um lado, afirma que o princípio ECQ não vale irrestritamente, i.é que nem de toda e qualquer contradição se segue trivialidade (onde tudo vale), e, de outro lado, reconhece (respectivamente deve reconhecer) que há (ou pode haver) concepções ou sistemas triviais, o que então implica que se reconhece que há (ou pode haver) contradições, para as quais vale o princípio ECQ, isto é, das quais se segue trivialidade. Esta posição "paraconsistente" só é coerente se se admite a distinção entre os dois tipos de contradição.

Segundo: todas e quaisquer lógicas, também as paraconsistentes, rejeitam sistemas (teorias, concepções) triviais. Isso já de per si pode e deve ser considerado uma verdade absoluta, pois que vale em todos os quadros referenciais teóricos. Se é posta a pergunta: porque também as lógicas paraconsistentes rejeitam tais sistemas (teorias, concepções) triviais?, não é difícil dar a resposta adequada: porque elas admitem implicitamente que há contradições que "geram" trivialidades, como foi mostrado. Mas isso significa que estas lógicas admitem contradições no sentido do conceito estrito/ forte acima explicado. Daqui se segue: o princípio de não-contradição no sentido estrito/forte do conceito de contradição é, em seu núcleo último, uma verdade absoluta. Diz-se "em seu núcleo último" porque há que distinguir entre "núcleo último" e diferentes formulações deste núcleo último de acordo com o quadro teórico pressuposto ou usado.

[6] O capítulo 4 de ES contém um breve argumento contra o fisicalismo. Dele Imaguire apresenta uma interpretação errada e a ele faz uma crítica correspondente sem nenhum valor probatório. O argumento de ES é estruturado pela figura chamada modus tollens: Se $p$, então $q$; ora não- $q$; portanto não- $p$. Em palavras: se o fisicalismo fosse verdadeiro $(=p)$, então deveria estar capacitado a dar uma explicação fisicalista do fato que a ciência estabelece afirmações verdadeiras sobre corpos celestes distantes vários bilhões de anos-luz da Terra $(=q)$; ora o fisicalismo não pode explicar este fato (= não- $q)$; portanto o fisicalismo não pode ser considerado uma concepção verdadeira (= não- $p$ ). 
A primeira premissa deve ser considerada como evidente: como o fisicalismo tem a pretensão de mostrar que tudo tem uma explicação fisicalista, deveria poder mostrar também como nosso conhecimento das galáxias distantes de nós bilhões de anos-luz pode ter uma explicação fisicalista.

O nervus probandi (ônus da prova) repousa na segunda premissa. Para prová-la ES recorre a um fenômeno que, à primeira vista, parece ser muito simples e sem problemas: o fenômeno de fazer uma afirmação verdadeira sobre algo no mundo. Em verdade, como ES mostra e aqui será exposto, este fenômeno tem imensas implicações, que, porém, praticamente são ignoradas, sobretudo por aqueles filósofos (em sua maior parte analíticos) que afirmam a necessidade de a filosofia se apoiar na ciência. Que significa e que implica afirmar algo de verdadeiro sobre algo no mundo? De uma ou outra forma, praticamente todas as teorias da verdade assumem que verdade constitui (ou segundo algumas teorias: pelo menos inclui necessariamente) uma relação do espírito humano àquilo, ao qual a afirmação verdadeira se refere no mundo. Esta relação foi chamada tradicionalmente de intencionalidade; hoje, após o linguistic turn, fala-se mais em relação semântica ou de referência. O essencial é ver que esta relação é uma relação ao real, a algo no mundo; em vista disso, essa relação deve ser uma relação também real. Como explicá-la? Todas as teorias, sejam elas fisicalistas (materialistas) ou não, devem explicar esta relação, do contrário o que é absolutamente central para as ciências e para a filosofia, a saber: a afirmação verdadeira sobre algo no mundo se reduz a uma tese ou afirmação vazia, que fundamentalmente nada diz, tornando, assim as ciências e a filosofia construções subjetivas, desconectadas do mundo real e, assim, sem nenhum valor. Mas a ciência tem seu valor inegável, o que implica que a relação em questão deve ser explicada.

Uma filosofia fisicalista, se é coerente, deve dar uma explicação fisicalista da relação-de-verdade. Mas como explicar fisicalisticamente a relação-deverdade com respeito a galáxias distantes de nós bilhões de anos-luz? Em geral, praticamente todos os filósofos fisicalistas simplesmente dizem que "sinais luminosos físicos", i. é raios enviados pelas galáxias precisamente há bilhões de anos-luz "chegam até nós", i. é. atingem nossa retina, assim que nesta base chegamos a saber que a galáxia tem esta distância com respeito a nós. Não há dúvida que sinais/raios chegam até nós. Mas nós (na medida em que nos identificamos com os cientistas) não fazemos afirmações sobre raios/sinais em nossas retinas, mas, em base de conhecimentos físicos pressupostos, interpretamos estes raios/sinais como provindo de galáxias com tal e tal distância com respeito a nós. E então fazemos afirmações verdadeiras não só sobre a distância das galáxias, senão também sobre sua constituição estrutural etc. Nós, assim, temos um conhecimento verdadeiro destas galáxias. Mas, a grande questão que aqui surge é: como é isso possível? A resposta filosófica só pode ser: Isso só é possível, se admitimos uma relação real de nós com respeito a tais galáxias. A razão é que as 
afirmações (científicas) são (consideradas como) verdadeiras, o que significa que elas se referem a galáxias reais. A relação-de-verdade é a relação de referência-a-galáxias-reais. Como explicar esta relação-de-referência? O fisicalismo, se é coerente com suas teses, só pode apresentar uma explicação fisicalista desta relação.

Uma explicação fisicalista, porém, não é possível, o que é fácil demonstrar. Tal explicação fisicalista consistiria em apresentar em termos fisicalistas como nós (ao fazer afirmações verdadeiras sobre as galáxias) podemos ter uma relação física com as galáxias, pois que, ao nos referir-nos às galáxias, estamos pressupondo que, por assim dizer, as "atingimos", "chegamos até elas", "as captamos". A relação deveria, por assim dizer, percorrer o percurso inverso ao percurso dos sinais/raios emitidos pelas galáxias e que, depois de bilhões de anos-luz, nos atingem. No quadro referencial teórico fisicalista, a relação real e, assim, física às galáxias deveria superar a distância de bilhões de anos-luz: de nós até as galáxias. Ora, uma das constantes fundamentais da natureza diz que a velocidade da luz se propaga a $300.000 \mathrm{~km} / \mathrm{s}$. Seria, portanto, absurdo admitir que, numa base fisicalista, nós poderíamos "atingir" as galáxias. Mas, ao fazermos afirmações verdadeiras sobre as galáxias, nós as "atingimos" realmente e a saber: num "instante". Fica evidente que o fisicalismo não pode explicar a relação-deverdade, sendo, assim, uma teoria vácua, infundada e incoerente.

Filósofos, que querem ou quisessem contestar este argumento contra o fisicalismo, são/seriam forçados a defender uma concepção da relação-deverdade que a reduz a algo de puramente subjetivo, por assim dizer, "em nossa cabeça". Dizem ou diriam que não é necessário admitir uma interpretação "realista" da relação-de-verdade. Contra tal defesa do fisicalismo pode-se apresentar um argumento extremamente forte: Filósofos fisicalistas reduzem todo o grande fenômeno da relação-de-verdade à esfera subjetiva do sujeito humano. Mas então são forçados a admitir uma espécie de milagre para "explicar" como nós, em base fisicalista, temos um conhecimento verdadeiro de galáxias a vários bilhões de anos-luz distantes da terra. Se um "milagre" é excluído, segue-se que o fisicalismo não dá uma explicação do fenômeno em questão, incorrendo assim numa incoerência autodestrutiva.

Imaguire faz afirmações fortes e contundentes contra o argumento apresentado em ES. Escreve: “Questionável é [...] em particular, a sua ideia [de Puntel] de que uma concepção da intencionalidade como estado subjetivo levaria a uma visão insustentável sobre o nosso conhecimento real do mundo: seria como um 'milagre [...] que nós humanos realmente podemos conhecer galáxias reais, o que implicaria que nós as 'alcançamos' ou 'encontramos' (Puntel, 2006, p. 473 [ES 472]). Não me parece, de forma alguma, que uma teoria do conhecimento fisicalista precise supor algum milagre para explicar que galáxias enviam sinais físicos que nos alcançam (nós não precisamos 'alcançá-las'), gerando em nós certos estados subjetivos que constituem conhecimento 'real'." (I 289) 
Imaguire não apresenta nem mesmo a mínima indicação de algum argumento contra a concepção de ES. Só faz afirmações que pretendem ser e são tanto mais contundentes quanto mais dogmaticamente estabelecidas. O que ele tem a dizer é só isto: Não lhe "parece" que o fisicalista "precise supor algum milagre"... Mas Imaguire deveria pelo menos insinuar de uma ou outra forma em que argumento pretende apoiar-se para justificar sua formulação subjetivista. Escamotear um problema não significa que o problema não exista. Imaguire deveria mostrar, pelo menos em princípio, como o fisicalista resolve o problema sem recorrer (o mais das vezes tacitamente) a um milagre. Acrescente-se que tal atitude é característica de muitos setores da filosofia analítica.

[7] Referindo-se ao capítulo 4 de ES Imaguire escreve: "A totalidade do real é constituída, segundo Puntel, por três domínios: o cosmológico, o religioso e o histórico." (I 290) Esta afirmação não é correta. Não se trata da totalidade "do real", mas da totalidade do "mundo". A palavra tão frequentemente usada"real(idade)" é extremamente ambígua e, quando é usada sem determinação precisa, dá azo a grandes mal-entendidos e cria problemas sem sentido; ES não a usa em afirmações importantes. O livro distingue cuidadosamente entre "Ser" e "mundo", sendo que "mundo" é definido como o conceito restritivo, em contra-distinção do conceito de "Ser", que é absolutamente ilimitado. Quanto aos três domínios: a cosmologia física, o fenômeno religioso e a história universal, ES estabelece que eles constituem a totalidade do mundo, i. é mundo considerado como um todo.

No contexto do capítulo 4 Imaguire faz uma observação crítica injustificada sobre o que ES expõe sobre o fenômeno religioso. Escreve: "Na avaliação das diferentes religiões mundiais, Puntel acentua o fato inegável de que somente o cristianismo desenvolveu uma teologia sistemática extremamente sofisticada. Mesmo que essa diagnose histórica seja correta, permanece questionável se desse fato contingente poderia ser extraída a conclusão de alguma superioridade intrínseca, em qualquer sentido dessa palavra, do cristianismo sobre as outras religiões. Pois é claro que esse fato histórico revela que o Deus cristão pode ser racionalmente pensado, mas o não desenvolvimento de uma teologia sistemática nas outras religiões não implica logicamente que isso não teria sido ou não é possível." (I 290).

Imaguire parece atribuir a ES a afirmação que o cristianismo é a religião, à qual se deve atribuir "uma superioridade intrínseca" com respeito às outras religiões. Mas ES não estabelece tal afirmação. O que ES diz é bem claro: o filósofo sistemático deve tematizar também o grande fenômeno religioso; mas, confrontado com a vastidão e a complexidade deste fenômeno, o filósofo deve decidir de que maneira pode e deve proceder. ES afirma então que um critério bem fundado para uma decisão realmente filosófica é o seguinte: o filósofo dará prioridade de atenção e tratamento àquela religião que desenvolveu um discurso teórico significativo, pois este é de interesse imediato para o filósofo. A única religião que fez isso é o cristianismo. Mais que isso 
ES não afirma, assim que a crítica de Imaguire se revela como sendo sem objeto e, assim, sem fundamento. Aqui se pode acrescentar que do fato de o cristianismo ser a única religião que elaborou um doutrina teoricamente sofisticada podem ser derivadas consequências muito importantes a respeito do estatuto do cristianismo em comparação com outras religiões. Mas esta problemática respectivamente a questão ulterior não é tematizada em ES.

[8] O capítulo 5 de ES tem como título: "Sistemática compreensiva: Teoria da interconexão de todas as estruturas e dimensões do Ser como teoria do Ser como tal e em seu todo." Imaguire apresenta até um certo ponto uma exposição acertada das teses centrais da secção 1, principalmente da tese que a linguagem filosófica é constituída de uma quantidade infinita não enumerável de expressões. Mas depois ele acrescenta uma observação crítica que merece consideração: "Mas a sua [de Puntel] suposição ontológica forte da linguagem, ou, mais geral, a sua concepção da natureza ontológica da dimensão teórica, segundo a qual não apenas mundo e sujeitos são entidades, mas também conceitos, teorias, etc., é surpreendente. [...] Os seus argumentos para essa ontologização radical e abrangente não me parecem convincentes. Ele afirma, por exemplo, para fundamentar a tese de que teorias são entidades reais, que sujeitos pensantes e teorias são produtos da evolução da natureza e que assim 'chegam à existência' (Puntel, 2006, p. 538 [ES 536]) no espaço e tempo e, mais, que 'teorias ocorrem na natureza'." (I 291)

Antes de tudo, deve-se ressaltar que Imaguire nesta passagem comete um grave erro de interpretação, erro que o leva a formular críticas infundadas e, assim, vazias. Na última frase da passagem ele atribui a ES a afirmação "que teorias são entidades reais, que sujeitos pensantes e teorias são produtos da evolução da natureza e que assim 'chegam à existência'". Imaguire não leu corretamente o que está dito em ES. Na pág. 536 ES articula a pergunta: "Esta tese [da ontologização] parece estranha e surpreendente?" Depois de acenar para o fato que muitos filósofos analíticos assim pensam, ES continua dizendo: "Na verdade, ainda mais surpreendente seria se essa tese não fosse encarada como evidente por filósofos analíticos. Afinal, o que ela é senão uma implicação de um truísmo fundamental afirmado pela ciência moderna? Porque para a ciência é um truísmo - isto é, uma afirmação assumida como verdadeira e transformada em atitude fundamental que o ser humano como um todo - e, assim, também o sujeito pensante e teorizador que emprega meios formais, conceituais etc. - é parte e até mesmo produto da evolução da natureza, algo que chega à existência em determinado momento da evolução cósmica."

Erroneamente, Imaguire atribui a ES o que ES atribui à ciência (moderna). Com isso, ES quer mostrar que a ontologização daquele mundo que Frege chama de "terceiro reino (drittes Reich)" (o que, diga-se de passagem, nada tem a ver com o "terceiro Reich" dos Nazistas) e Popper chama de "terceiro mundo", i. é o mundo (ou, como ES costuma dizer, a dimensão) teórico/a dos pensamentos (no sentido objetivo de Frege, i. é das proposições), das 
estruturas formais, dos conceitos, das teorias etc. é algo que as ciências e todos os filósofos de orientação fisicalista sempre já pressupõem, mas até agora não tematizaram e, segundo ES, não estão capacitados a tematizar. A passagem citada de Imaguire é muito significativa, pois que ela, involuntariamente, expressa aquilo que constitui umas das grandes fraquezas da corrente analítica, que é a seguinte: De uma parte, a corrente analítica (mais exatamente: aquela grande parte desta corrente que pensa nos moldes do fisicalismo) quer reduzir tudo, portanto também o "terceiro reino e terceiro mundo" ao "mundo" entendido como a totalidade das coisas físicas. De outra parte, esta corrente (mais exatamente: grande parte dela) separa estritamente o "terceiro reino e terceiro mundo" do mundo "físico". Cometendo uma clara incoerência, rejeitase neste segundo aspecto, como Imaguire faz, a "ontologização" das dimensões que Frege chama "terceiro reino" e Popper "terceiro mundo". As soluções que Imaguire sugere (platonismo, nominalismo...) não resolvem o problema, pois o problema real não é encarado e tratado.

O problema real reside na tarefa de formular um conceito unitário do mundo: o conceito de mundo que abrange tanto os três reinos de Frege como os três mundos de Popper, sem que isso se faça ao detrimento da especificidade de cada uma das dimensões. É isso o que ES chama de ontologização. Esta é a grande tarefa, tarefa que é exposta em ES, mas que Imaguire ignora. Uma concepção abrangente do mundo não permitiria falar ingenuamente como fazem as descrições comuns que se encontram em tantos livros (mesmo em livros assim chamados "científicos") da evolução com a afirmação de que tudo (assim também o segundo e o terceiro reinos/mundos) "chegam à existência", i. é surgem ou emergem no decurso da evolução. Tais afirmações são uma espécie de ontologização, mas se trata de uma ontologização errada, pois não faz de nenhuma maneira justiça ao caráter específico do segundo e terceiro reino/mundo A razão disso é a falta de um conceito abrangente e adequado de mundo.

A este respeito cabe fazer neste contexto uma indicação ao que acontece na filosofia analítica. Quine foi o filósofo que como talvez nenhum outro incorporou a ideia central e a atitude característica da filosofia analítica. Se se perguntar: Que conceito de mundo elaborou Quine?, a resposta é altamente significativa: Não elaborou explicitamente um conceito de mundo, pois em consideração a todas as questões a esse respeito dizia: "The answer is naturalism: the recognition that it is within science itself, and not in some prior philosophy, that reality is to be identified and described." ${ }^{4}$ Mas isso não o impede de defender a tese de que existem duas espécies de objetos: os físicos e os abstratos: "So we assume abstract objects over and above the physical objects." Em outra passagem diz: "Ordinary interpreted scientific

\footnotetext{
${ }^{4}$ QUINE, W. V., Theories and Things. Cambridge, MA/Londres: The Belknap Press of Harvard University Press, 1981, 21.

5 Ibid. 15.
} 
discourse is irredeemably committed to abstract objects - to nations, species, numbers, functions, sets - as it is to apples and other bodies. All these things figure as values of the variables in our overall system of the world. The numbers and functions contribute just as genuinely to physical theory as do hypothetical particles. ${ }^{\prime 6}$ Mas então a questão surge: Como conceber o mundo como composto destas duas espécies de "objetos" tão radicalmente diferentes? Seria um mundo concebido fisicalisticamente? Isso seria abertamente incoerente. Este é um dos característicos enigmas subjacentes à filosofia elaborada por pelo menos grande parte dos filósofos que se dizem analíticos.

Nesse contexto cabe fazer uma observação final sobre a linguagem filosófica infinita. Imaguire escreve: "Mas se teorias 'chegam à existência' por meio de uma evolução natural, torna-se incompreensível de que maneira essa sua linguagem abstrata com um número não enumerável de expressões 'chegaria à existência', se ela nunca é atualizada. Ou se admite um Platonismo de entidades da linguagem e teorias ('teorias não são criadas, elas são descobertas') e se abdica, conseqüentemente de afirmações sobre entidades que 'chegam à existência', ou se assume uma posição mais nominalista e, então, se assume a tarefa de mostrar como tal linguagem infinita chega à existência (o que, naturalmente, não pode ser feito, posto que nunca seria plenamente atualizável)." (I 291) Imaguire faz um uso impróprio da expressão "chegar à existência" (de teorias etc.). Como já foi dito acima, ES atribui este "chegar à existência", assim concebido (como Imaguire o descreve), às descrições que se encontram em geral na literatura que se diz "científica". A esta literatura "científica" Imaguire deveria dirigir sua pergunta.

Uma concepção nominalista não seria de nenhum modo apropriada para caracterizar o conceito abrangente de mundo que ES tem em mira. Mas também o platonismo, como é entendido em geral, não favorece o conceito de um mundo unitário. Ao contrário do nominalismo, porém, é possível conceber diferentemente o platonismo, assim que ele admite pode ser parte integrante do mundo abrangente. Neste caso o platonismo é nada mais que a articulação do caráter específico do terceiro reino/mundo. E este terceiro reino/mundo é uma das três grandes dimensões que constituem o mundo abrangente. Esta concepção pode ser bem ilustrada, ao considerar uma observação crítica final de Imaguire sobre a linguagem infinita: "[S]e teorias "chegam à existência" por meio de uma evolução natural, torna-se incompreensível de que maneira essa sua linguagem abstrata com um numero não enumerável de expressões 'chegaria à existência', se ela nunca é atualizada." (I 291; cursivo não está no original)

O verdadeiro problema e a real tarefa aparecem, quando se formula a questão: Quantas expressões contêm as linguagens assim-chamadas naturais efetivamente faladas e usadas? A resposta parece óbvia: uma quantidade

\footnotetext{
6 Ibid.149-150.
} 
finita (ou então, em certo sentido, uma quantidade infinita, mas numerável). Pode-se apontar para um dicionário que cataloga o número e o significado das palavras de uma linguagem. Mas isso acontece num determinado tempo ou numa determinada situação. Em verdade, uma linguagem, que é fundamentalmente um sistema semiótico, só pode ser adequadamente caracterizada se se leva em conta todas as suas potencialidades. Estas se tornam manifestas na forma de uma construção (matemática) de uma quantidade infinita não enumerável de expressões desta linguagem. ${ }^{7}$

Este fato tem uma notável consequência: todas as linguagens que falamos ou usamos, tanto na vida quotidiana como no plano científico e filosófico, são apenas fragmentos da respectiva linguagem que possui uma quantidade infinita não enumerável de expressões. O importante é notar aqui que tais linguagens são partes integrantes do mundo abrangente. Nós vivemos e pensamos, por assim dizer, "dentro" de um enorme todo, do qual captamos e usamos apenas fragmentos, mas isso na base do conhecimento que este todo é uma quantidade infinita não enumerável de expressões.

[9] O último ponto a ser tratado se refere a uma das teses mais centrais do livro ES. O ápice da parte 5 de ES com o título "Sistemática Compreensiva" é a Teoria do Ser como tal e como um Todo. Trata-se da explicação do que ES chama a dimensão primordial do Ser, ou simplesmente: o Ser primordial. O passo decisivo é a introdução das modalidades: possibilidade, necessidade, contingência. Como resultado de longas considerações metodológicas, que Imaguire ignora por completo, é apresentada uma prova cuja conclusão é a bi-dimensionalidade do Ser primordial, i. é a distinção entre a dimensão do Ser absolutamente necessário e a dimensão do Ser contingente (que é a totalidade dos entes contingentes). A prova é uma prova indireta segundo a figura do modus tollens. Consiste em refutar a tese de que tudo (compreendendo por "tudo" o Ser mesmo e a totalidade dos entes) é contingente, i. é a tese onicontingenteísta.

Em brevíssimo resumo, a prova é formulada assim:

Se absolutamente tudo - e, assim, a própria dimensão do Ser - fosse contingente, dever-se-ia assumir a possibilidade do nada absoluto.

Ora, o nada absoluto não é possível.

Portanto, nem tudo, isto é, não toda a dimensão do Ser é contingente.

Uma sequela do argumento é fácil de expor: Se não toda a dimensão do Ser é contingente, então há uma dimensão não-contingente, i. é uma dimensão necessária do Ser. A expressão "dimensão" é usada aqui para evitar a palavra "algo" (na formulação: "então há algo não-contingente"), que já é demasiadamente "concreta", pois que "algo" induz admitir a equiparação:

\footnotetext{
${ }^{7}$ Ver sobre isso ES, especialmente a secção 5.1.4.3.2.1, pp. 502 ss.
} 
"algo=ente". O termo "dimensão" é suficientemente neutro para evitar malentendidos e, assim, preservar a coerência de toda a concepção.

Um pequeno passo ulterior é o adicionamento do conceito de "absoluto". Como ES o entende, este conceito especifica o conceito de necessário, o que se pode mostrar brevemente. Da palavra "absoluto" e, de maneira especial, da forma adverbial "absolutamente" faz-se na literatura filosófica amplo emprego, o que acontece também no presente artigo. Pode-se parafrasear o sentido do vocábulo de diferentes maneiras, mas certamente a significação fundamental, pelo menos no uso filosófico, é relativamente clara: "Absoluto" significa "incondicionado". O estatuto de (algo) "incondicionado" pode ser entendido de duas maneiras: ou significa não-relacionalidade (a qualquer item que seja) ou, havendo relacionalidade, esta não pode ter um relatum condicionante, $\mathrm{o}$ que seria uma relacionalidade que implica dependência. O que é absoluto em sentido estrito e exato é o que é de modo total incondicionado.

Nesta base pode-se mostrar que a dimensão necessária do Ser é absoluta, i. é incondicionada em sentido estrito e exato. Se a dimensão necessária do Ser não estivesse relacionada a qualquer item que seja, então também não estaria condicionada por qualquer item que seja. Seria incondicionada, portanto absoluta. Mas assumindo que a dimensão necessária do Ser tenha uma relacionalidade a um relatum não-condicionante, isso não afetaria de modo nenhum o caráter incondicionado (e, assim absoluto) da dimensão necessária do Ser, pois que um relatum não-condicionante não cria nenhuma dependência. Assuma-se, porém - hipoteticamente (i. é aqui a título meramente argumentativo) - que a dimensão necessária do Ser esteja ou pudesse estar relacionada a um relatum condicionante, então surgiria uma contradição, o que não pode coerentemente ser aceito. A demonstração é fácil. Por definição, o Ser necessário não pode não ser. De onde se deve deduzir: Se a dimensão necessária do Ser não fosse absoluta (e, assim absolutamente necessária), isso significaria que ela estaria condicionada por algum item que não seria a dimensão necessária do Ser. Ora, por definição, um item que não fosse a dimensão necessária do Ser só poderia ser uma dimensão contingente do Ser. Mas se a dimensão necessária do Ser estivesse condicionada pela dimensão contingente do Ser, a dimensão necessária não mais seria dimensão necessária, pois então estaria "afetada" ou "determinada" por contingência, tornando-se, assim, algo de contingente, i. é, algo que é, mas poderia não ser. O que contradiz o conceito de dimensão necessária do Ser. Logo a dimensão necessária do Ser é a dimensão absolutamente necessária do Ser.

Note-se que esta argumentação está à base da intuição que induziu uma grande tradição do pensamento ocidental (sobretudo a tradição concretizada no Idealismo Alemão) a introduzir e usar o substantivo "o Absoluto". Mas note-se, igualmente, que esta intuição nunca foi articulada de modo preciso e adequado. 
Voltando à prova em questão, fica claro que a primeira premissa não é outra coisa que a análise da tese onicontingenteísta, o que não será explicado aqui. Mas note-se que se introduz o conceito da possibilidade do nada absoluto como incluído analiticamente na tese onicontingenteísta. O ônus da prova recai na segunda premissa. ES apresenta dois argumentos. O primeiro aponta para o fato de o conceito de nada absoluto ser um conceito paradoxal, autocontraditório neste sentido um pseudoconceito: Quando se quer determiná-lo, diz-se já algo, mas algo já é um modo de ser, contradizendo, assim, o conceito de nada absoluto. Se esse conceito é paradoxal, autocontraditório, segue-se que não é possível, pois que nada designa. $\mathrm{O}$ segundo argumento é uma espécie de "experimento de pensamento", que, em vista do argumento, abstrai do caráter paradoxal e autocontraditório do pseudoconceito "nada absoluto". (Para abreviar a exposição usar-se-ão aqui os termos "ser" e "existir" como sinônimos, como faz Imaguire, contrariando, assim, a importante distinção que ES introduz entre os dois termos.) Assuma-se que nada tivesse sido ou existido; "ter-se-ia", assim, o nada absoluto. Mas então a questão surgiria: já que sabemos que "coisas" são ou existem, dever-se-ia dar uma explicação de como pensar a "passagem" do nada absoluto à dimensão das coisas que são ou existem, i. é à dimensão do Ser. Ora tal explicação é pura e simplesmente impossível. Seria uma passagem de "algo" para "algo", assim algo, que é um modo de ser, já estaria pressuposto. É simplesmente impossível pensar uma tal passagem.

Imaguire não apresenta o argumento como tal e muito menos o examina em detalhe. Escreve algumas frases e depois afirma taxativamente, pondo a palavra "prova" entre aspas: "Essa 'prova' pode ser rejeitada por diferentes motivos." (I 291) (Todas as citações que seguem, até nova indicação, se encontram na p. 291 da resenha.) Dada a importância da prova para o livro ES e para tornar claro o modo de pensar do autor da resenha, analisar-se-á no que segue frase por frase todo o parágrafo, que ele dedica a expor seus "motivos".

Imaguire afirma: " Em primeiro lugar, a aplicação do operador modal (que é um operador sentencial) ao nada (que certamente não é uma sentença, proposição ou nada equivalente) é um erro sintático." Esta afirmação é surpreendente. Primeiramente, o operador modal não é só um operador sentencial (no sentido estrito de ser restringido somente ao plano sintático), mas é principalmente um operador proposicional (entendendo por "proposicional" aquilo que uma sentença exprime: a proposição). Pode-se dizer que o operador modal é um operador sentencial somente se se pressupõe que a sentença (que é o argumento do operador) é uma sentença-queexprime-uma-proposição. Imaguire omite tudo isso, causando com isso malentendidos com consequências graves, como se mostrará.

Ao afirmar que o operador modal é um erro sintático, pois que na prova é aplicado ao nada (e não a uma sentença/proposição), Imaguire comete um gravíssimo erro de interpretação. Ele ignora por completo - o que para um 
crítico é fatal - as explicações minuciosas que ES apresenta numa secção especial (5.3.1) com o título "Esclarecimentos preliminares" precisamente ao introduzir a prova. Na p. 588 de ES lê-se: "Na lógica modal, as modalidades são entendidas como operadores que têm como argumentos sentenças ou as proposições expressas por elas. Caso se queira tratar qualquer tema mediante recurso às modalidades e, ao fazê-lo, proceder bem rigorosamente segundo as determinações da lógica modal, deve-se aplicar com exatidão todas essas determinações. Porém, na elaboração de um ponto de partida para uma teoria do Ser absolutamente necessário, não se procederá segundo esse modo bem rigoroso. A argumentação será exposta, antes, de modo programático e, assim, apenas informal. Isto significa, entre outras coisas, que aqui as expressões modais não serão empregadas [do ponto de vista sintático] única nem principalmente como operadores, mas na maioria das vezes, como ocorre na linguagem natural e em quase toda a história da filosofia, numa posição predicativa e/ou atributiva: como fatores ontológicos que competem a determinadas entidades ('existe uma dimensão do Ser necessária e uma dimensão do Ser contingente' etc.)."

Na mesma página ES esclarece mais outro ponto, que, no presente contexto, é essencial: "A exposição a seguir [da prova, da qual é questão aqui] é de caráter extremamente simplificado e abreviado também sob outro aspecto. Ela não procede rigorosamente segundo as determinações fundamentais da 'semântica contextual' desenvolvida em traços básicos no capítulo 3." Segundo esta semântica, que é parte absolutamente essencial da concepção estrutural-sistemática exposta em ES, na linguagem filosófica pressuposta e usada só são admitidas sentenças sem a estrutura de sujeito e predicado, sentenças chamadas primas, portanto sentenças como "chove". Isso vale para a dimensão semântica, não para a dimensão sintática. Sentenças com a estrutura sintática de sujeito e predicado podem ser usadas (e, na prática filosófica, é praticamente impossível prescindir do seu uso), mas devem se transformadas semanticamente. Isso significa: na linguagem estritamente reconhecida e usada pela filosofia sistemático-estrutural as sentenças com a estrutura sintática de sujeito e predicado são consideradas como abreviações cômodas de um grande número de sentenças primas. Esta concepção é uma extensão sistemática da ideia de Quine que introduziu o procedimento chamado "eliminação dos termos singulares". ${ }^{8}$ Evidentemente, Quine continuou a falar e escrever em inglês normal, usando sentenças sintaticamente compostas de sujeito (termo singular) e predicado, mas semanticamente transformando-as em sentenças sem termos singulares.

O resultado destas explicações apresentadas em ES e da concepção semântica elaborada e exposta no capítulo 3 desta obra para a problemática tratada presentemente é claro: a prova, de que aqui se trata, não comete nenhum erro sintático; o operador modal se aplica a uma expressão (pri-

${ }^{8}$ Ver sobre isso as longas explicações em ES (secção 3.2.2.3.2.3, pp. 258 ss.). 
meiramente à expressão "nada absoluto)" considerada semanticamente como uma abreviação de uma sentença prima (e, assim, de uma proposição prima expressada por ela), que é altamente complexa (ou, equivalentemente, como uma abreviação de um grande número de sentenças primas e, assim, de proposições primas). Se se quisesse exprimir tal sentença numa linguagem "natural" como o português, haveria que recorrer a uma construção linguística estranha. Haveria que dizer (por exemplo): o termo "nada absoluto" é uma abreviação da sentença prima altamente complexa: "está nadificando absolutamente". (Observe-se que a construção talvez mais natural seria: "está nadando absolutamente", mas, como é evidente, "nadando" remete ao verbo "nadar".) Para ilustrar este estado de coisas, pode-se apontar aqui para o procedimento de Quine, que formula o resultado da eliminação do termo singular (nome próprio) "Sócrates" dizendo: "x (ou: it) Socratizes". 9

Imaguire ignora tudo isso, o que é extremamente surpreendente por parte de um crítico, do qual se deve supor que leu atentamente a obra que se propõe resenhar. $\mathrm{O}$ que ele afirma na continuação do seu texto não tem nenhum valor probatório, pois que é o resultado do grave erro de interpretação recém demonstrado. Ele escreve: “Mas se 'possível $X^{\prime}$ não é sintaticamente correto, então 'não possível $X^{\prime}$ também não poderia ser aceito como sintaticamente correto, posto que esta é apenas a negação da primeira." Esta constatação do ponto de vista estritamente lógico é certa. O que é errado é a aplicação que Imaguire faz desta condição lógica à prova de ES. Para repetir, como foi mostrado: esta prova não comete absolutamente nenhum erro sintático, assim que a aplicação não tem vez.

Na p. 292 Imaguire continua: "Em segundo lugar, na prova se faz uso da noção de 'absoluto nada', apesar de que o autor considera essa noção um 'impensável anti- ou pseudo-conceito' (undenkbarer Unbegriff). Uma prova que faz uso essencial de um pseudoconceito é, na melhor das hipóteses, uma pseudoprova. E se tal conceito não for um pseudoconceito, então a conseqüência pretendida da sua impossibilidade de 'realização' ('atualização', ou qualquer outra noção similar) não poderia mais ser extraída." Trata-se aqui de um jogo de palavras. O que Imaguire não considera é o caráter absolutamente único do conceito de "nada absoluto". Se se chama este conceito de "pseudoconceito" ou "conceito impensável" ou, como está dito em ES, "conceito autocontraditório" é uma questão de terminologia; a

\footnotetext{
${ }^{9}$ Note-se que Quine não é suficientemente e coerentemente radical em seu procedimento de eliminar termos singulares, como se mostra longamente em ES (secção 3.2.2.3.2.3, p. 258 ss.). Ele mantém, apesar de tudo, a linguagem e a lógica de predicados de primeira ordem: "I mean predicate logic not as the initial or inevitable pattern of human thought, [...] but as the adopted form, for better or worse, of scientific theory." (QUINE, W. O., "Events and Reification", in: E. LePore/B. P. McLaughlin (eds.), Actions and Events. Perspectives on the Philosophy of D. Davidson. Oxford: Blackwell, 1985, 162-171; cit. 170) ES supera essa posição de Quine, radicalizando-a no sentido que sentenças com a estrutura de sujeito e predicado são rejeitadas (com respeito à dimensão semântica e, assim, também ontológica).
} 
única coisa importante é atender à explicação que ES dá do uso da expressão "pseudoconceito".

O que se quer exprimir é o fato de que o conceito de nada absoluto é absolutamente sui generis, é, por assim dizer, um absoluto singulare tantum no plano conceptual. É um conceito que exprime - e exprime de maneira autocontraditória - negação, mas negação absoluta, o que nenhuma outra negação, por mais forte que se possa considerar, exprime. Com efeito, toda outra negação sempre é uma negação só em sentido relativo, entendendo isso da seguinte maneira: tal negação sempre nega algo de determinado, mas não nega simplesmente tudo. Por exemplo, "não- $p$ " nega $p$, mas não nega (por exemplo) $q, r$, s...Mas o conceito de nada absoluto é uma negação absolutamente inigualável, incomparável, um absoluto singulare tantum, pois qualquer coisa (seja o que for), a totalidade de coisas (seja qual for a maneira como se conceba esta totalidade) é por ele excluída. ES usa duas outras expressões: o nada absoluto é um conceito "paradoxal" e "autocontraditório". É neste sentido que o conceito de nada absoluto é chamado de "pseudoconceito"; "pseudoconceito" é aqui entendido como conceito absolutamente autocontraditório

Caracterizar a prova como pseudoprova, é jogar com palavras para efeitos retóricos. Tais "joguetes" não são aceitáveis numa discussão filosófica. Ao afirmar: "Uma prova que faz uso essencial de um pseudoconceito é, na melhor das hipóteses, uma pseudoprova", Imaguire não se dá conta que comete um sofisma: usa a expressão "pseudoconceito" não no sentido apenas explicado do autor de ES, mas em seu próprio sentido que nem é exposto. Imagine-se que alguém apresente o seguinte raciocínio: "Se tudo fosse permitido no plano teórico, então o caos absoluto seria possível; ora o caos absoluto não é possível; portanto não tudo é permitido no plano teórico." Assumamos que este alguém fundamente a segunda premissa dizendo que o conceito de caos absoluto é um conceito absurdo. Teria então sentido dizer que a prova é "uma prova absurda"? Mas é isso o que Imaguire, seguindo seu modo de proceder com relação à prova de ES, deveria dizer. Não é a prova que é absurda, senão que a prova tira as consequências de uma absurdidade (neste caso a segunda premissa) que resulta da afirmação a ser refutada (neste caso o antecedente da primeira premissa). Assim também na prova de ES: a prova tira as consequências do fato que o conceito de nada absoluto é um conceito autocontraditório e, neste sentido e por esta razão, é um pseudoconceito. Transformando semanticamente o termo "nada absoluto" em uma sentença prima, como foi explicado acima, dever-se-ia dizer: a prova tira as consequências do fato que a proposição prima expressada pela sentença "está nadificando absolutamente e totalmente" é uma proposição autocontraditória e, neste sentido e por esta razão, é uma pseudoproposição.

Imaguire acrescenta: "E se tal conceito [do nada absoluto] não for um pseudoconceito, então a conseqüência pretendida da sua impossibilidade 
de 'realização' ('atualização', ou qualquer outra noção similar) não poderia mais ser extraída." Como não? A impossibilidade do nada absoluto segue do fato que este conceito (como quer que seja que se o denomine) inclui uma autocontradição: ao querer explicitá-lo, fica claro que se pressupõe o que o conceito pretende absolutamente excluir. Ora, se uma afirmação (neste caso o antecedente da primeira premissa da prova de ES) implica a possibilidade de um X (seja conceito ou sentença prima) autocontraditório, deve ser claro que, para usar formulações de Imaguire, a impossibilidade da "realização" ou "atualização" deste X não só pode, senão que deve forçosamente ser "extraída". De onde se segue que o antecedente da primeira premissa é refutado.

Por fim Imaguire afirma: "Finalmente, se fosse correto que nem tudo é contingente, seguiria apenas das suas definições (Puntel, 2006, p. 590 [ES 589]) que necessariamente existe algo, mas não que existe algo 'absolutamente necessário' (o que o próprio autor explicitamente não quer identificar com simplesmente 'necessário'), ou seja, incondicionado e completamente independente. Afinal, 'provado' (supondo que a prova foi conclusiva) foi apenas que o 'absoluto nada' não é possível, de onde se segue que pelo menos alguma coisa precisa existir necessariamente - mas isso não implica que essa coisa que existe seja necessária ('é necessário que exista algo' não é equivalente a 'existe algo que é necessário'), e muito menos absolutamente necessário (incondicionado)." (I 292) Aqui Imaguire recorre à famosa distinção entre de dicto e de re, assumindo, sem nenhuma prova, que ela se aplica à conclusão da prova apresentada em ES. Este ponto final será detalhadamente examinado no que segue.

Uma primeira resposta à crítica de Imaguire consiste em, hipoteticamente (i. é aqui: a título meramente argumentativo), assumir suas formulações adequadamente estruturadas respectivamente estruturáveis por uma linguagem e lógica quantificacionais de primeira ordem. Diz-se aqui "hipoteticamente" porque esta maneira de reconstruir a prova não condiz de nenhuma maneira com o que ela deve e pretende mostrar. Mas mesmo nos quadros das suposições formais de Imaguire, sua afirmação não se segue. Ele diz: "Afinal, 'provado' (supondo que a prova foi conclusiva) foi apenas que o 'absoluto nada' não é possível, de onde se segue que pelo menos alguma coisa precisa existir necessariamente." Depois ele esclarece esta última afirmação, introduzindo a distinção entre duas afirmações: a afirmação (1): "É necessário que exista algo" e a afirmação (2): "Existe algo que é necessário", acrescentando, o que é evidente, que as duas afirmações não são equivalentes. Imaguire continua dizendo que a afirmação geral "pelo menos alguma coisa precisa existir necessariamente", que segue da prova (segundo ele, supostamente conclusiva), "não implica" a afirmação (2): "existe algo que é necessário". Disso deve-se concluir que Imaguire quer dizer que da prova (segundo ele, supostamente conclusiva) só segue a afirmação (1): "é necessário que exista algo". 
Pode-se mostrar que a afirmação de Imaguire (dentro do seu quadro formal) é infundada. Para criar clareza, recomenda-se que se formalize as duas afirmações (1) e (2). Para cada uma delas apresentar-se-ão duas versões formalizadas - (a) e (b) para (1) e (a') e (b') para (2) -, dependendo de como se queira entender e tratar o conceito de existência. As versões (a) e ( $a^{\prime}$ ) tratam existência como sendo "definida" pelo quantificador existencial " $\exists x^{\prime}$ " (existe um $x$ assim que...), enquanto que as versões (b) e (b') introduzem e tratam existência como um predicado: "EX $x$ " ( $x$ existe). Em base destas pressuposições, as versões formalizadas podem ser expostas do seguinte modo (o símbolo " $\Omega$ " designa o operador da necessidade):

(1) "É necessário que exista algo": (a) $\Omega \exists x(x=a)-$ (b) $\Omega \exists x(E X x)$

(2) "Existe algo que é necessário": (a') $\exists x \Omega(x=a)-\left(b^{\prime}\right) \exists x \Omega(E X x)$

Qual afirmação se segue da prova em ES? Já que a prova é informal, devese decidir esta questão apelando para o que a prova quer dizer. Ora, não pode haver dúvida que a prova quer atribuir as modalidades contingênciapossibilidade-necessidade não ao modo de descrever (o que muitas vezes se chama de dicto, como na afirmação (1)), mas sim às "coisas" mesmas, como isso articulado na formulação do próprio Imaguire: "Pelo menos alguma coisa precisa existir necessariamente." Atendendo a este fator (i. é: ao que a prova intuitivamente e informalmente quer dizer), deve-se concluir que a conclusão da prova é a afirmação (2) (que comumente se chamaria de re, ou seja: afirmação ontológica).

Note-se, como já dito acima, que esta primeira resposta é só hipotética (no sentido explicado). A total inadequação desta maneira de reconstruir a prova é fácil de mostrar, o que se fará articulando a segunda resposta. A total inadequação reside no fato que a primeira resposta (que, a título meramente argumentativo, assume os meios formais usados por Imaguire) trata só de coisas, seja como for que se chamem (entes, indivíduos, "algos" etc.) Ora a prova de ES pretende mostrar que se trata de responder a questão se o Ser mesmo (o Ser como tal e como um todo) é ou não é contingente. Ora, os meios usados por Imaguire de nenhuma maneira são adequados para formalizar o discurso sobre o Ser. Já acima se indicou que ES elabora uma nova semântica na qual não há termos singulares e predicados (em sentido estrito), pois a linguagem filosófica admitida não aceita sentenças com a estrutura de sujeito e predicado. Só aceita sentenças "primas", que são sentenças sem sujeito e predicado, como "chove", "amanhece", "está fazendo calor", "está sendo (= essenciando)" (ver abaixo) etc.

Como se disse acima, para facilitar a exposição a prova foi apresentada sem explicitar as sentenças primas como tais envolvidas na prova; a prova usa sentenças comuns com sujeito e predicado, assim que a prova tem uma exposição intuitiva e informal. Mas em base da semântica exposta em ES e seguindo as explicações dadas na introdução à exposição da prova, a forma 
linguística da exposição da prova deve ser entendida de tal modo que aconteça a transformação semântica requerida. Executar isso mostra que tal operação não é possível sem infligir uma certa "violência" à linguagem natural falada. Será dado aqui um exemplo de tal transformação linguisticamente algo "violenta".

A premissa "Se absolutamente tudo, o próprio Ser, fosse contingente, então o nada absoluto seria possível" pode ser transformada na linguagem filosófica (segundo ES) da seguinte maneira: "Se é contingente que está sendo (ou essenciando) absolutamente e totalmente, então é possível que está (estivesse) nadificando absolutamente." Explicação: a formulação "está sendo (ou essenciando)" é a sentença prima que é abreviada pelo termo "Ser". "Sendo" entende-se, porque se refere a "Ser"; "essenciando" supõe "essenciar", sendo que este termo é um neologismo usado em muitas traduções de textos de Heidegger ao português (inspira-se do termo latino "esse"). A letra "S" simboliza a sentença (respectivamente a proposição por ela expressada): "está sendo (ou essenciando) absolutamente e totalmente". O antecedente da primeira premissa da prova pode então formalizar-se assim (usando o símbolo " $\nabla$ " para designar o operador modal "é contingente que...): “(Se) $\nabla S^{\prime}$. Quanto ao consequente: a letra " $\mathrm{N}$ " abrevia a sentença "está (estivesse) nadificando absolutamente". Com o operador "é (seria) possível que...", designado pelo símbolo " $\diamond$ ", o consequente pode formalizar-se assim: "(então) $\diamond \mathrm{N}$ ". A primeira premissa obtém, assim, a formalização: $\nabla \mathrm{S} \rightarrow \diamond \mathrm{N}$. Em base destas explicações a prova integral é exposta de modo exato da seguinte forma extremamente simples:

$$
\begin{aligned}
& \nabla \mathrm{S} \rightarrow \diamond \mathrm{N} \\
& \neg \diamond \mathrm{N} \\
& -\square \\
& \neg \nabla \mathrm{S}
\end{aligned}
$$

Como se pode facilmente ver, não há aqui margem para interpretações errôneas e objeções nelas baseadas do tipo das que Imaguire apresenta em sua resenha.

Uma observação final: a conclusão da prova é negativa e diz "só" o seguinte (numa formulação sintaticamente própria da linguagem comum): "Não é o caso que tudo, i. é o Ser como tal e como um todo, é contingente." Numa linguagem um tanto "violenta" condizente com a semântica exposta em ES e correspondente à formalização $\neg \nabla S$, dever-se-ia dizer: "Não é o caso que é contingente que está (estaria) sendo/essenciando absolutamente e totalmente." Mas desta conclusão negativa segue-se imediatamente que o ope- 
rador "é necessário que..." deve ser introduzido, pois que este operador é a negação do operador "é contingente que..." (e, assim, também do operador "é possível que..."). Na versão informal e intuitiva isso é expresso dizendo: (deve-se admitir) uma dimensão necessária (e absoluta) do Ser. Na versão semanticamente (e logicamente) exata (segundo a concepção semântica elaborada em ES) dever-se-ia dizer: (deve-se admitir) que não é contingente que está sendo/essenciando absolutamente e totalmente.

Esta conclusão deve ser cuidadosamente interpretada. Ela nega (nas duas versões) que seja o caso que a dimensão do Ser como tal e como um todo seja contingente respectivamente que seja o caso que seja contingente que está sendo/essenciando absolutamente e totalmente. Dependendo de como se interpreta esta dimensão necessária, a conclusão não exclui que nela haja também contingência; só exige que haja em todo caso necessidade. Ora, sabemos que há "coisas ou entes" contingentes. Para exprimir este estado de coisas, ES introduz a expressão "bi-dimensionalidade do Ser": a dimensão absolutamente necessária e a dimensão contingente (e, com isso, a subdimensão possível) do Ser. A partir deste ponto a tarefa de elaborar a teoria do Ser como um todo consistirá essencialmente em esclarecer a relação entre a dimensão absolutamente necessária do Ser e a dimensão contingente do Ser (i. é, a dimensão dos entes contingentes). O capítulo 5 do livro ES contém um breve esboço desta teoria. Um livro posterior do autor com o título Ser e Deus - um enfoque sistemático em confronto com M. Heidegger, É. Lévinas e J.-L. Marion ${ }^{10}$ apresenta uma exposição mais elaborada da mesma teoria.

\section{Endereço do Autor:}

Philosophie Department - Universität München

Geschwister-Scholl-Platz 1

80539 München - Alemanha

puntel@lrz.uni-muenchen.de

10 S. Leopoldo, RS: Editora Unisinos, 2011. A edição original alemã com o título Sein und Gott - ein systematischer Ansatz in Auseinandersetzung mit M. Heidegger, É. Lévinas und J.-L. Marion foi publicada pela Editora Mohr Siebeck, Tubinga, em 2010. 